University of Nebraska - Lincoln

DigitalCommons@University of Nebraska - Lincoln

Publications, Agencies and Staff of the U.S.

Department of Commerce

U.S. Department of Commerce

2011

Lipid class dynamics and storage depots in juvenile weakfish Cynoscion regalis and their application to condition assessment

S. Y. Litvin

Rutgers University - New Brunswick/Piscataway

V. G. Guida

NOAA

M. P. Weinstein

Montclair State University

Follow this and additional works at: https://digitalcommons.unl.edu/usdeptcommercepub

Part of the Environmental Sciences Commons

Litvin, S. Y.; Guida, V. G.; and Weinstein, M. P., "Lipid class dynamics and storage depots in juvenile weakfish Cynoscion regalis and their application to condition assessment" (2011). Publications, Agencies and Staff of the U.S. Department of Commerce. 287.

https://digitalcommons.unl.edu/usdeptcommercepub/287

This Article is brought to you for free and open access by the U.S. Department of Commerce at DigitalCommons@University of Nebraska - Lincoln. It has been accepted for inclusion in Publications, Agencies and Staff of the U.S. Department of Commerce by an authorized administrator of DigitalCommons@University of Nebraska - Lincoln. 
doi:10.1111/j.1095-8649.2011.02918.x, available online at wileyonlinelibrary.com

This article is a U.S. government work, and is not subject to copyright in the United States

\title{
Lipid class dynamics and storage depots in juvenile weakfish Cynoscion regalis and their application to condition assessment
}

\author{
S. Y. LitVin*†, V. G. Guida $\ddagger$ And M. P. Weinstein \\ *Institute of Marine and Coastal Sciences, Rutgers University, 71 Dudley Road New \\ Brunswick, NJ 08901, U.S.A., \$NOAA, National Fisheries Service, Northeast Fisheries \\ Science Center, 74 Magruder Road, Highlands, NJ 07732, U.S.A. and §Institute for \\ Sustainability Studies, Montclair State University, Mallory Hall 116E, Montclair, \\ NJ 07043, U.S.A.
}

(Received 22 April 2010, Accepted 19 January 2011)

\begin{abstract}
Lipid class dynamics, the pattern of change in the primary form and location of lipid stores and their relationship with standard length $\left(L_{\mathrm{S}}\right)$, were investigated in collections of young-of-the-year weakfish Cynoscion regalis for the purpose of determining the utility of this analysis as an indication of condition. The separation of total lipids into individual classes and the analysis of potential storage depots revealed the general patterns of lipid class dynamics and energy storage in C. regalis during their period of juvenile estuarine residency. Phospholipid and cholesterol exhibited moderate but variable (8.1-40.0 and $1.3-21.5 \mathrm{mg} \mathrm{g}^{-1}$, respectively) concentrations across the entire juvenile period and were the predominant lipid classes in juveniles $<100 \mathrm{~mm} L_{\mathrm{S}}$, while wax ester concentrations were low (c. $1 \mathrm{mg} \mathrm{g}^{-1}$ ) and exhibited the least amount of variability among lipid classes. Triacylglycerols (TAG) and free fatty acids (FFA) exhibited similar dynamics, with relatively low concentrations $\left(<15 \mathrm{mg} \mathrm{g}^{-1}\right)$ in individuals $\leq 100 \mathrm{~mm} L_{\mathrm{S}}$. In larger juveniles both TAG and FFA concentrations generally increased rapidly, though there was considerable variability in both measures (0.0-199.7 and $0 \cdot 0-49.7 \mathrm{mg} \mathrm{g}^{-1}$, respectively). Increasing levels of lipids, primarily in the form of TAG, with size indicated an accumulation of energy reserves with growth, thus providing an indication of individual condition for larger juveniles. Separate analysis of liver, viscera and the remaining carcass indicated that liver and viscera did not represent a significant depot of TAG reserves. Analysis of samples derived from whole juvenile $C$. regalis thus provided an accurate estimate of energy reserves.

(C) 2011 The Authors

Journal of Fish Biology @ 2011 The Fisheries Society of the British Isles
\end{abstract}

Key words: biochemical condition; free fatty acids; lipid allocation, lipid storage; triacylglycerol.

\section{INTRODUCTION}

Variability in the strength of recruitment among year classes is a major focus in fisheries research and is thought to be determined largely during the early life stages of development (Houde, 1987; Ralston, 1995; Sogard, 1997). Marine transient

$\dagger$ Author to whom correspondence should be addressed at present address: Hopkins Marine Station, Stanford University, 120 Oceanview Boulevard, Pacific Grove, CA 93950, U.S.A. Tel.: +1 831655 6251; email: litvin@ stanford.edu 
species (Deegan et al., 2000) spawn along the Atlantic and Gulf coasts of the U.S.A. and produce offspring that recruit to shallow estuarine habitats. For these species, post-settlement survival, growth, energy allocation and young-of-the-year (YOY) recruitment success may be governed by a number of factors (Shuter \& Post, 1990; Walters \& Juanes, 1993; Kneib, 2003). Initially, size-selective predation represents their primary source of mortality and therefore energy tends to be allocated to somatic growth. Later in the juvenile period, allocation of energy shifts towards long-term storage in preparation for the impending demands associated with offshore migration and overwintering (Post et al., 1997; Sogard, 1997; Hurst, 2007). While overwintering, starvation due to energy deficits is considered a major form of mortality, with environmental conditions and the magnitude of energy reserves governing the likelihood of survival (Post \& Lee, 1996; Schultz \& Conover, 1997; Biro et al., 2004; Hurst, 2007).

To understand the effects of environmental variability and competing energy demands on the survival potential of YOY fishes, there has been a focus on developing measures of biochemical condition, including those based on the energy stored as lipids. Lipids can be readily utilized during deficit periods due to food shortages or metabolically stressful conditions (Shulman \& Love, 1999). While total lipid content is often used as an indicator of biochemical condition (Shuter \& Post, 1990; Schultz \& Conover, 1999), the ability to endure energy deficits may be dependent on the magnitude of endogenous stores of specific lipid classes (Norton et al., 2001; Finstad et al., 2004; Naesje et al., 2006). Among these classes, triacylglycerols (TAG) are principal energy reserves for most finfishes beyond the yolk-sac stage and have been used as a principal indicator of biochemical condition (Doucett et al., 1999; Norton et al., 2001; Lochmann \& Ludwig, 2003; Weinstein et al., 2009, 2010), though other neutral lipids, such as mono- and di-acylglycerols, free fatty acids (FFA), cholesteryl esters and wax esters (WE), may be important forms of long-term energy stores (Lochmann et al., 1995).

Lipid storage depots may occur in numerous locations in finfishes: subcutaneous connective tissue, skeletal muscle, the abdominal cavity (particularly in the mesenteries and pyloric caeca), the liver, interosseous tissue and at the base of the fins (Jobling et al., 1998; Shulman \& Love, 1999; Morgan et al., 2002). As a rule, a given species has several lipid depots, with the sequence of their utilization depending on the functional state and nature of the processes requiring energy reserves. Generally, utilization of reserves is in the order: liver lipid to mesenteric lipid to muscle lipid to muscle proteins, e.g. in Atlantic cod Gadus morhua Linnaeus 1758 (Black \& Love, 1986; Shulman \& Love, 1999). Liver lipid concentrations, however, may not vary with physiological state. In their study of Atlantic salmon Salmo salar Linnaeus 1758 during migration, Doucett et al. (1999) noted that lipid levels in the liver were slightly reduced. They attributed this observation to the central role the liver plays in lipid metabolism and concluded that maintenance of levels in the liver was accomplished via lipid mobilization from areas of less importance to the liver during migration.

The objective of this study was to assess the feasibility of utilizing lipid class analysis as a metric of biochemical condition for future studies of juvenile weakfish Cynoscion regalis (Bloch \& Schneider 1801), a marine transient species. If feasible, an additional objective was to identify the most appropriate and efficient sampling 
protocol (whole individuals or specific tissues) to determine their condition. Specifically, variability in lipid classes and the relationship between mass $(M)$ and standard length $\left(L_{S}\right)$, both of whole individuals and in specific tissues, in a temperate population of YOY $C$. regalis were compared to determine: (1) the dynamics of individual lipid class concentrations over the YOY period, (2) the distribution of lipid reserves within tissues (liver, viscera and remaining carcass) and (3) the differences, if any, in estimates of lipid reserves based on analysis of whole individuals $v$. specific tissues.

\section{MATERIALS AND METHODS}

\section{FIELD COLLECTIONS}

Juvenile C. regalis were collected in August through to October of 1999 and 2000 with otter trawls towed near low tide for 10 min during daytime and night-time hours in tidal salt marsh creeks across the length of the New Jersey shore of Delaware Bay. Marsh creeks sampled were Alloway Creek, a 1253 ha meso-oligohaline Phragmites australis-dominated marsh, Mad Horse Creek, a relatively undisturbed 1558 ha mesohaline marsh, and two Spartina alterniflora-dominated meso-polyhaline systems: Dennis Creek, an undisturbed 1100 ha marsh, and West Creek, a nearby 234 ha formerly diked salt hay farm. In addition, juvenile $C$. regalis were collected at the mouth of Delaware Bay prior to their emigration from the system in early November of 1999.

Fish were measured for $L_{\mathrm{S}}$ to the nearest $\mathrm{mm}$ and quickly frozen and preserved on dry ice until transported to the laboratory and storage at $-80^{\circ} \mathrm{C}$ (Ohman, 1996). An effort was made to collect individuals from three size classes: $<60 \mathrm{~mm}$ (I), 60-100 mm (II) and $>100 \mathrm{~mm} L_{\mathrm{S}}$ (III). These size classes reflect ontogenetic shifts in the trophic niche of juvenile $C$. regalis from specialization on crustaceans when $<60 \mathrm{~mm}$, to an increasing proportion of fishes while in the second size class to roughly equal proportions of crustaceans and fishes when $>100 \mathrm{~mm}$ (Chao \& Musick, 1977; Grecay \& Targett, 1996a; Nemerson, 2001).

\section{LABORATORY ANALYSIS}

Two hundred and seventy-two $C$. regalis $24-200 \mathrm{~mm} L_{\mathrm{S}}(39,145$ and 88 in size classes I, II and III, respectively) were selected to discern lipid class dynamics over the juvenile period. Partially thawed fish were cleaned of gut contents (Lochmann et al., 1995, 1996), then subsequently freeze-dried to a constant $M$ before grinding to fine powder (i.e. amalgamation, Spex CertiPrep 5100 grinding mill; www.spexsampleprep.com). Fish $<120 \mathrm{~mm}$ $L_{S}$ were ground whole, while those $\geq 120 \mathrm{~mm} L_{S}$ were first coarse ground in a Waring (www.waringproducts.com) stainless steel blender and a random aliquot was then selected for grinding to a fine powder. Eighty individuals $25-182 \mathrm{~mm} L_{\mathrm{S}}$ (43, 21 and 16 in size classes I, II and III, respectively) collected from the four marsh creeks between August and October 1999 were utilized to compare the distribution of TAG among juvenile $C$. regalis tissues. Partially thawed fish were dissected to isolate liver, viscera (including mesenteries) and remaining carcass. Each component was separately freeze-dried, weighed $\left[M_{\mathrm{D}_{\mathrm{C}}}\right.$, where $C$ = component, $L$ (liver), $V$ (viscera) or $R$ (remaining carcass)] and ground to a fine powder. An exception was liver and viscera from smaller fish which were not ground and underwent biochemical analysis whole to avoid significant loss of material. All samples were stored in pre-combusted glass vials with acid-washed polyethylene caps and purged with $\mathrm{N}_{2}$ gas to exclude airborne oxygen and prevent lipid peroxidation prior to storage at $-80^{\circ} \mathrm{C}$.

A $50 \mathrm{mg}$, range $49-55 \mathrm{mg}$ sub-sample, if available, of ground amalgamated fish or component (liver, viscera or remaining carcass) was folded into a $70 \mathrm{~mm}$ diameter Whatman 541 ashless filter paper (www.whatman.com) and extracted three times, first in 4.0 ml of 2:1 (v/v) dichloromethane: methanol for $15 \mathrm{~h}$ at $5^{\circ} \mathrm{C}$ (vial headspace purged with $\mathrm{N}_{2}$ ), then in $3.0 \mathrm{ml}$ of fresh solvent mixture for $3 \mathrm{~h}$, followed by a final $3 \mathrm{~h}$ extraction in $2 \mathrm{ml}$ of fresh solvent 
mixture. The three sequential extracts were combined and stored at $-80^{\circ} \mathrm{C}$ under $\mathrm{N}_{2}$ for no more than 4 days to avoid esterification of fatty acids by methanol in the extraction solvent (Parrish, 1987). To each extract, $50 \mu \mathrm{g} \mu^{-1}$ nonadecane $\left(\mathrm{C}_{19} \mathrm{H}_{40}: 1.000 \mathrm{mg}\right.$ total $)$ internal standard (for $50 \mathrm{mg}$ samples reconstituted to $0.5 \mathrm{ml}$ or adjusted to preserve the concentration of standard relative to the final sample volume) in chloroform was added and back extraction in $0.1 \mathrm{M}$ aqueous $\mathrm{KCl}$ solution at $5^{\circ} \mathrm{C}$ (Folch et al., 1957) was used to remove non-lipid materials. Back-extracted samples were concentrated by evaporating to dryness in a $38^{\circ} \mathrm{C}$ water bath under a stream of $\mathrm{N}_{2}$ gas and then reconstituted in $0.5-1.5 \mathrm{ml}$ of dichloromethane, depending on sample size and lipid content.

Lipid classes in these extracts were separated using a modification of the method of Lochmann et al. (1995) in which 1-2 $\mu$ l aliquots of lipid extracts were spotted on Iatron Chromarod III silica-coated rods (www.iatroscan.com) and partially developed in three successive HPLC grade solvent systems. Modifications included the placement of a desiccant into the first two development tanks to lower humidity, extending development duration to $45 \mathrm{~min}$ for better definition of polar classes and drying Chromarods for $3 \mathrm{~min}$ at $90^{\circ} \mathrm{C}$ prior to analysis. Flame ionization detector (FID) scanning using an Iatroscan Mark V with a Hewlett Packard HP3690 integrator was used for data acquisition. Blanks, a combined synthetic standard that included hydrocarbon (nonadecane), WE (palmitic acid stearyl ester), triacylglycerol (tripalmitin), FFA (palmitic acid), fatty alcohol (1-hexadecanol = cetyl alcohol), sterol (ST) (cholesterol), monoacylglycerol (1-monopalmitoyl-rac-glycerol), phospholipid (PL) (phosphatidylcholine), and one replicate for every seven samples were utilized to determine lipid class concentrations and ensure accuracy. Conversion of FID peak areas to extract lipid concentrations was performed using a segmented third-order polynomial calibration model with separate curves generated for each standard and each Chromarod set used. Because the standards did not represent all lipid classes present in fishes, peaks not corresponding to standards were converted to concentrations using a model representing the average response for the eight specified classes. Conversion of all peaks provided a measure of all classes, and therefore total lipid concentration, when summed.

\section{STATISTICAL ANALYSIS}

The dynamics of individual lipid class concentrations in juvenile $C$. regalis were investigated for WE, TAG, FFA, ST, PL, as well as total lipids, all expressed as $\mathrm{mg} \mathrm{g}^{-1}$ dry $M$. ST and PL are major structural lipids classes with unambiguous FID peaks while TAG and WE represent potential long-term energy stores. FFA, a metabolic intermediate and potential short-term energy source, was considered the sum of the FFA plus methyl esters (ME) from the analysis because ME most likely originates from the methylation of FFA in the extraction process (Parrish, 1987). Differences and variability in the concentrations of the five lipid classes, total lipid concentration and per cent of total lipid concentration in the form of TAG for individual YOY C. regalis were examined over the entire range of $L_{S}$ via fitting a nonparametric locally weighted smoothing function (LOWESS; tension $=0.5$; Cleveland, 1981) ignoring size class boundaries.

To assess the patterns and distribution of storage lipids within juvenile $C$. regalis across liver, viscera and the remaining carcass, component TAG concentration $\left([T]_{\mathrm{C}}\right)$, allometries of component dry $M$ and component TAG content (in $\mathrm{mg}, T_{\mathrm{C}}$ ) were considered. TAG content in a given component was estimated: $T_{\mathrm{C}}=[T]_{\mathrm{C}} M_{\mathrm{D}_{\mathrm{C}}}$, where $C=$ component, $L, V, R$.

An allometric model was used to characterize the changes of all three measures across the size range of YOY C. regalis analysed:

$$
[T]_{\mathrm{C}}, M_{\mathrm{D}_{\mathrm{C}}} \text { or } T_{\mathrm{C}}=\alpha_{\mathrm{C}} L_{\mathrm{S}}^{\beta_{\mathrm{C}}}, \text { where } C=\text { component, } L, V, R
$$

where $\alpha_{\mathrm{C}}$ and $\beta_{\mathrm{C}}$ are the scale and rate parameters that were fitted by performing leastsquares linear regression on $\ln [T]_{\mathrm{C}}, M_{\mathrm{D}_{\mathrm{C}}}$ or $T_{\mathrm{C}}$ and $\ln L_{\mathrm{S}}$ (Bagenal \& Tesch, 1978). Dry $M$ was examined over the entire size range ignoring class boundaries while for $[T]_{\mathrm{C}}$ and $T_{\mathrm{C}}$ a stage-specific approach was utilized where separate models were fitted for each size class. 
Differences in accumulation patterns and distribution of biomass $\left(M_{\mathrm{D}_{\mathrm{C}}}\right),[T]_{\mathrm{C}}$ and $T_{\mathrm{C}}$ among components were assessed via comparison of rate parameters (general linear models, GLM) and ANCOVA with natural logarithm of $L_{\mathrm{S}}$ as the covariate.

To compare estimates of individual juvenile $C$. regalis TAG concentration from different methods, i.e. extraction of samples from amalgamated whole individuals $\left([T]_{\mathrm{W}}\right) v$. those from separate components, a whole body estimate of TAG concentration $\left([T]_{\mathrm{E}}\right)$ was calculated from the analysis of components:

$$
[T]_{\mathrm{E}}=\left(T_{\mathrm{L}}+T_{\mathrm{V}}+T_{\mathrm{R}}\right)\left(M_{\mathrm{D}_{\mathrm{L}}}+M_{\mathrm{DV}_{\mathrm{V}}}+M_{\mathrm{D}_{\mathrm{R}}}\right)^{-1}
$$

Individuals used to compare the extraction methods were sub-sampled from the same collection (sampling location and date) in order to eliminate possible spatio-temporal effects. A stage-specific allometric model (equation 1) was used to characterize the distribution of estimated individual TAG concentrations from both extraction methods and differences among the methods evaluated via ANCOVA with $\ln L_{\mathrm{S}}$ as the covariate. All statistical analyses were performed in SYSTAT 12.0 (www.systat.com).

\section{RESULTS}

While there was substantial variability in the concentration of the five lipid classes and the overall concentration of lipids for a YOY C. regalis of a given size, definite trends within the data were apparent (Fig. 1). Concentrations of total lipids

(a)

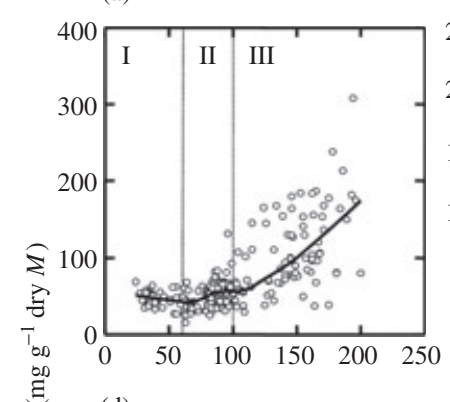

(b)
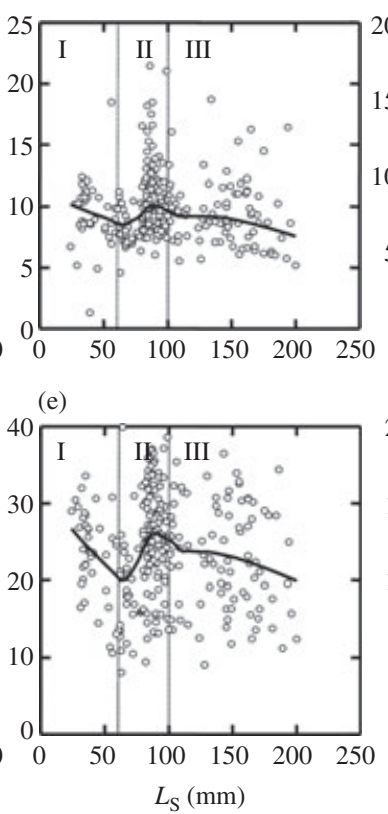

(c)
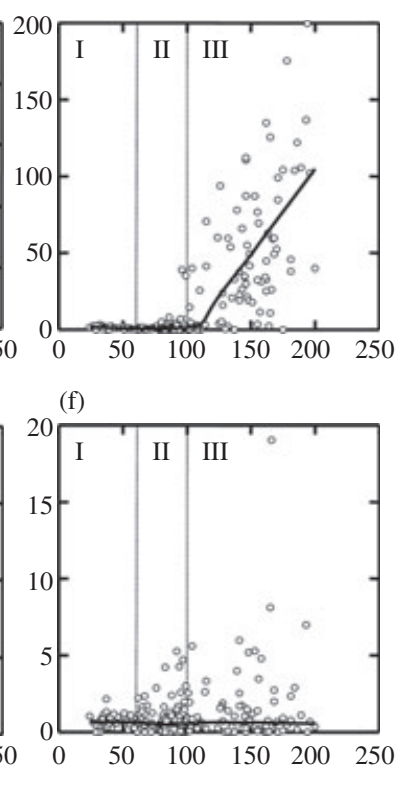

FIG. 1. Changes in the concentration of (a) total lipid, (b) sterol, (c) triacylglycerol, (d) free fatty acids, (e) phosphatidylcholine and (f) waxy esters with standard length $\left(L_{S}\right)$ for juvenile Cynoscion regalis over stages I to III. Lines represent a locally weighted smoothing function (LOWESS; tension $=0 \cdot 5$; Cleveland, 1981) fit over the $L_{\mathrm{S}}$ range, regardless of stage. 
varied widely over the juvenile period, up to 20 -fold, but generally increased with individual $L_{\mathrm{S}}$ with the preponderance of the accumulation occurring $>100 \mathrm{~mm} L_{\mathrm{S}}$ (Fig. 1). Total lipid concentrations of YOY $C$. regalis in size classes I and II averaged $52.1 \pm 14.6 \mathrm{mg} \mathrm{g}^{-1}$ (mean \pm S.D.) and, with one exception, were $<100 \mathrm{mg} \mathrm{g}^{-1}$ while individuals within the third size class exhibited a pattern of rapid lipid accumulation to $>300 \mathrm{mg} \mathrm{g}^{-1}$ among the largest fish analysed. Phospholipid was the predominant lipid class in YOY $C$. regalis in size classes I and II, beyond which TAG concentrations exceed that of PL. Both PL and ST showed moderate but variable concentrations, $8 \cdot 1-40.0$ and $1 \cdot 3-21.5 \mathrm{mg} \mathrm{g}^{-1}$, respectively, throughout the YOY period, declining slightly over the largest $L_{\mathrm{S}}$ class. Concentrations of WE were low, $c .1 \mathrm{mg}$ $\mathrm{g}^{-1}$, and exhibited the least amount of variability among lipid classes. Triacylglycerols and FFA had similar dynamics, with relatively low concentrations in the smaller $L_{S}$ classes followed by a rapid increase in larger juveniles. For FFA, concentration in size classes I and II generally varied between 2 and $15 \mathrm{mg} \mathrm{g}^{-1}$ and increased upwards of five-fold in C. regalis $>100 \mathrm{~mm} L_{\mathrm{S}}$. TAG concentrations were at or near zero (i.e. below detection level) in smaller fish, began to increase between 60 and $100 \mathrm{~mm}$ $L_{\mathrm{S}}$ then increased rapidly to almost $200 \mathrm{mg} \mathrm{g}^{-1}$ in size class III. In the largest size class, however, there was considerable variability in the measured concentrations of TAG (0.0-199.7 $\left.\mathrm{mg} \mathrm{g}^{-1}\right)$ and FFA $\left(0 \cdot 0-49.7 \mathrm{mg} \mathrm{g}^{-1}\right)$. When viewed as a percentage of total lipid concentration, the predominant role of TAG in large juveniles is highlighted, increasing rapidly in the third size class and reaching upwards of $75 \%$ (Fig. 2). Because of its probable role as the predominant lipid class utilized by juvenile $C$. regalis for long-term energy storage, subsequent analysis focused on TAG.

Generally, carcasses, livers and viscera of juveniles in size classes I and II contained $<10 \mathrm{mg} \mathrm{g}^{-1}$ TAG [Fig. 3(a)], with $36 \%$ of the individuals components having

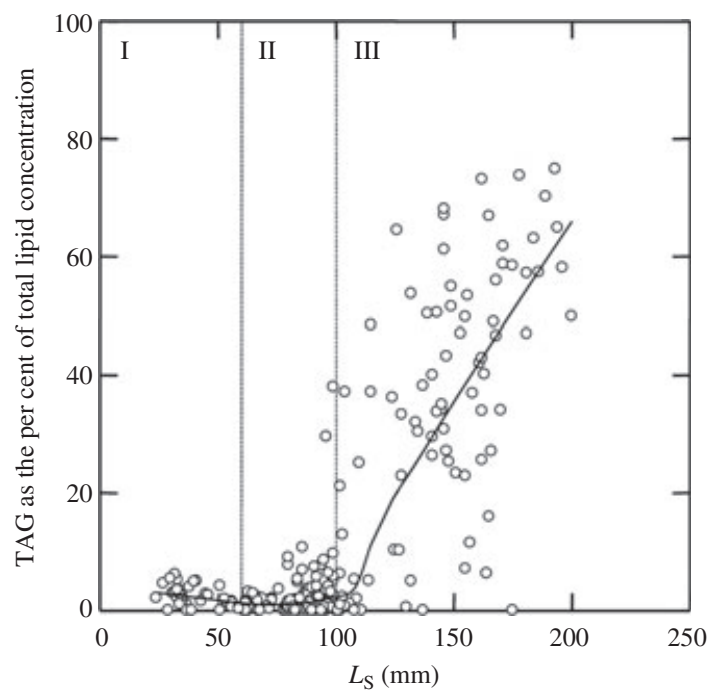

FIG. 2. Triacylglycerol (TAG) as the percentage of total lipid concentration as a function of standard length $\left(L_{\mathrm{S}}\right)$ in juvenile Cynoscion regalis over stages I to III. Line represents a locally weighted smoothing function (LOWESS; tension $=0 \cdot 5$; Cleveland, 1981) fit over $L_{\mathrm{S}}$, regardless of stage. 

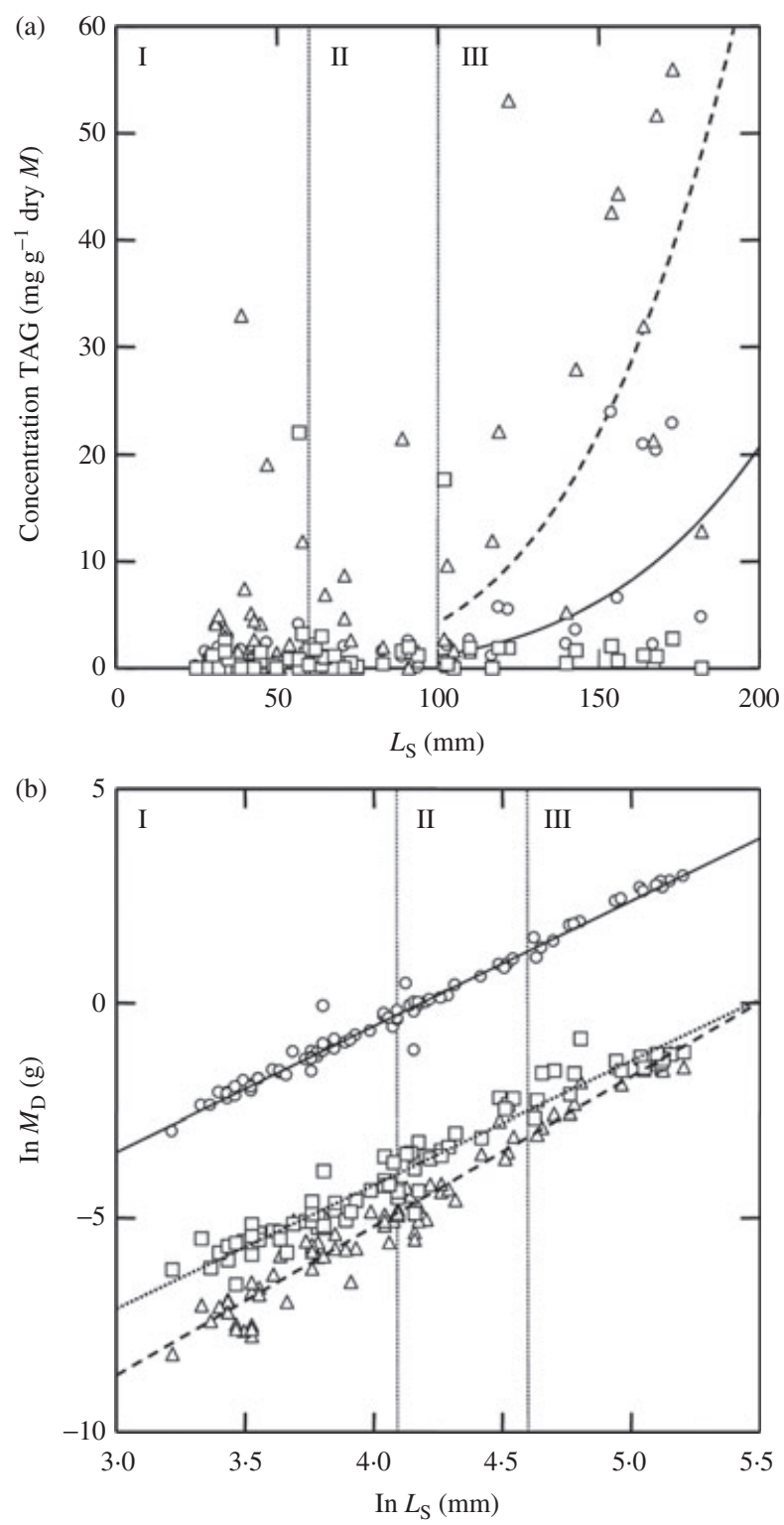

FIG. 3. (a) Concentration of triacylglycerol (TAG) in carcasses $(O)$, livers $(\triangle)$ and viscera $(\square)$ and (b) dry mass $\left(M_{\mathrm{D}}\right)$ of each component as a function of standard length $\left(L_{\mathrm{S}}\right)$ in juvenile Cynoscion regalis from stages I to III. (a) Stage-specific and (b) full $L_{\mathrm{S}}$ range allometric model fits [see Table I(a), (b) for coefficient estimates, respectively] for carcasses (__ $)$, livers (. . _ ) and viscera (............).

no measurable TAG [Table I(a)]. As the lack of TAG content could reflect poor condition, individual components with no measurable TAG were excluded when fitting allometric models. Of the components sampled from $C$. regalis in size classes I and II with measurable TAG, none exhibited a significant pattern of increase with $L_{\mathrm{S}}$ [Table I(a)] $(P>0.05)$. Above $100 \mathrm{~mm} L_{\mathrm{S}}$, TAG concentrations in viscera 


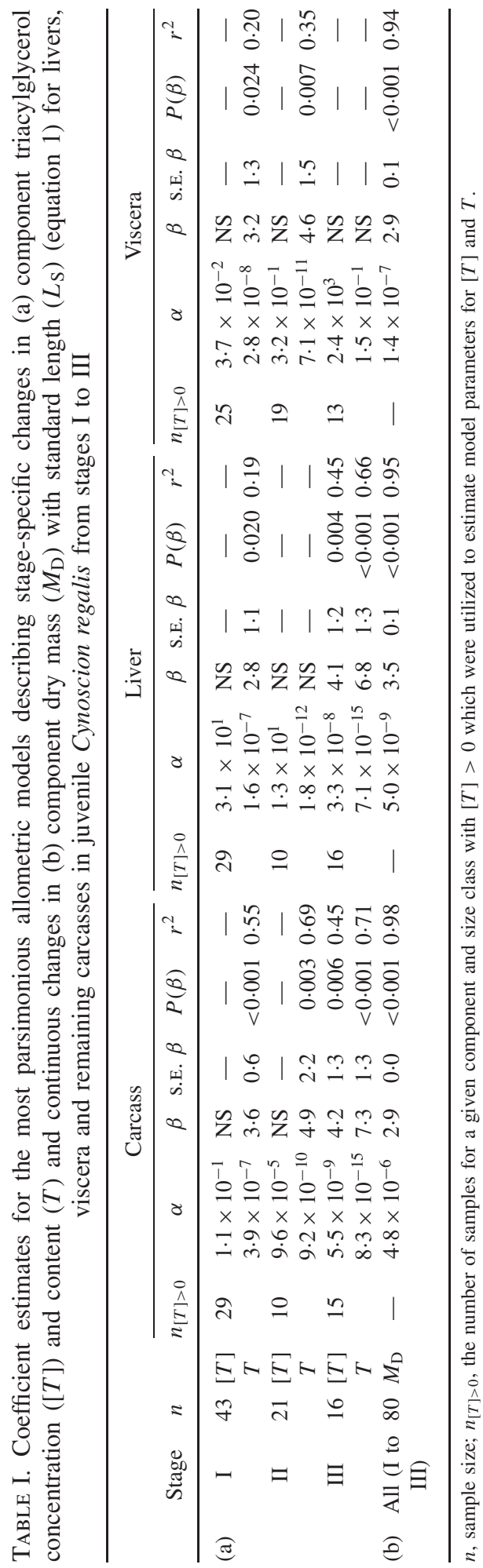


remained low and did not increase with $L_{\mathrm{S}}(P>0.05)$ while concentrations in both livers and carcasses increased with $L_{S}$ at a similar rate [Table I(a)] (GLM, $P>0.05)$ with livers containing higher TAG concentrations relative to carcasses (ANCOVA, $P<0 \cdot 01$ ). As in YOY analysed whole, however, TAG concentrations in livers and carcasses of fish $>100 \mathrm{~mm} L_{S}$ exhibited a great deal of variability [Fig. 3(a)]. Unlike TAG concentrations, the relationship between dry $M$ and $L_{\mathrm{S}}$ [Fig. 3(b)] was tight across the entire size range of YOY C. regalis carcasses, livers and viscera [Table $\mathrm{I}(\mathrm{b})]$. While the carcasses represents the majority of biomass across all $L_{\mathrm{S}}$ (mean 96\%), the rate of increase with $L_{\mathrm{S}}$ was slightly higher in livers relative to carcasses and viscera (GLM, $P<0 \cdot 01$ ). The relative distribution of stored TAG among components was a function of the increasing concentration of TAG in livers and carcasses of juveniles $>100 \mathrm{~mm} L_{S}$ and the allometries of component dry $M$ (Fig. 4). In juveniles $<100 \mathrm{~mm} L_{\mathrm{S}}$, significant increases in TAG content were generally comparable to increases in component biomass [Table I(a)]. Among individuals in size class III, TAG content in viscera exhibited no discernable increase with $L_{\mathrm{S}}(P>0.05)$, while content in both livers and carcasses increased with $L_{\mathrm{S}}$ at a similar accelerated rate (Table II), (GLM, $P>0.05)$. This reflects the interaction of increasing concentrations and allometric growth in both components from YOY $>100 \mathrm{~mm} L_{\mathrm{S}}$ [Table I(a), (b)], with carcasses containing higher TAG content relative to livers (ANCOVA, $P<0.005$ ). Irrespective of size class or the factors (relative biomass or TAG concentration) driving the relative distribution, the proportion of TAG stored within the caresses of juvenile $C$. regalis was high, with a mean \pm S.D. of $94.8 \pm 6.2 \%$ in the 54 individuals with carcass TAG concentrations $>0$ (Fig. 4).

The TAG concentrations from extraction of 107 whole YOY C. regalis 24-200 $\mathrm{mm} L_{\mathrm{S}}(39,46$ and 22 in size classes I, II and III, respectively), collected from the

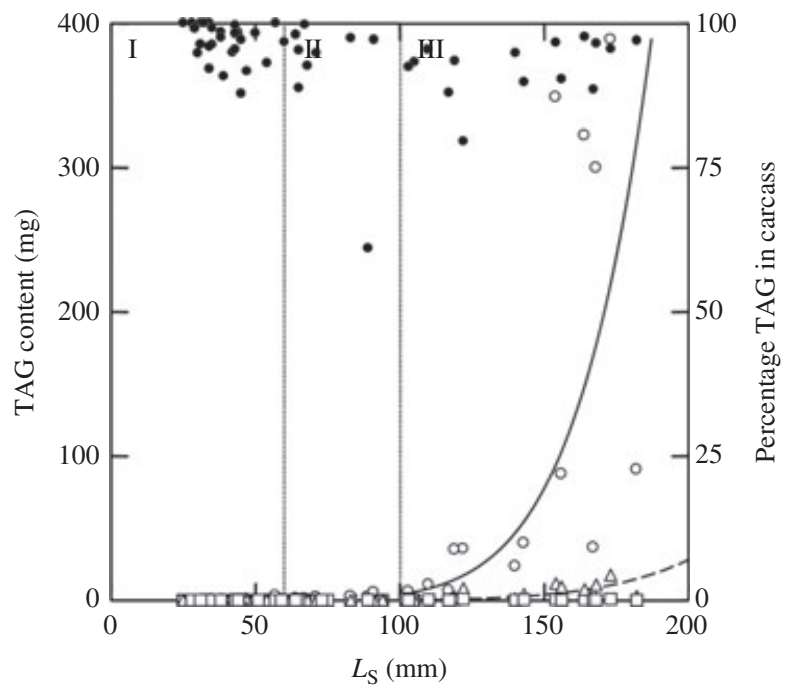

FIG. 4. Triacylglycerol (TAG) content of carcasses $(O)$, livers $(\triangle)$ and viscera $(\square)$ and percentage of TAG located in the carcass $(-)$ as a function of standard length $\left(L_{S}\right)$ in juvenile Cynoscion regalis from stages I to III. Stage III specific allometric model fits [see Table I(a) for coefficient estimates] for carcasses (_) and livers (_- _ $)$. 
TABLE II. Coefficient estimates for the most parsimonious stage-specific allometric models describing changes in triacylglycerol content $(T)$ estimated from extraction of samples from amalgamated whole individuals and separate components (carcasses, liver and viscera; see equation 2) with standard length $\left(L_{S}\right)$ (equation 1) in juvenile Cynoscion regalis from stages I to III

\begin{tabular}{|c|c|c|c|c|c|c|c|c|c|c|c|c|c|}
\hline \multirow[b]{2}{*}{ Stage } & \multicolumn{6}{|c|}{ Extraction of amalgamated whole individuals } & \multicolumn{7}{|c|}{ Extraction of components } \\
\hline & $n n_{[T]>0}$ & $\alpha$ & $\beta$ & S.E. $\beta$ & $P(\beta)$ & $r^{2}$ & $n$ & $n_{[T]>0}$ & $\alpha$ & $\beta$ & S.E. $\beta$ & $P(\beta)$ & $r^{2}$ \\
\hline I & 39 & $2 \cdot 1 \times 10^{3}$ & $-2 \cdot 1$ & 0.5 & $<0.001$ & $0 \cdot 36$ & 43 & 41 & $4.9 \times 10^{-2}$ & NS & - & - & 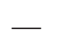 \\
\hline II & 46 & 1.6 & NS & - & - & - & 21 & 21 & $1.7 \times 10^{-7}$ & NS & - & - & - \\
\hline III & 21 & $1.3 \times 10^{-13}$ & $6 \cdot 5$ & $1 \cdot 0$ & $<0.001$ & 0.71 & 16 & 16 & $2.1 \times 10^{-10}$ & $4 \cdot 8$ & 1.2 & 0.001 & 0.53 \\
\hline
\end{tabular}

$n$, sample size; $n_{[T]>0}$, the number of samples for a given analysis type and size class with TAG concentrations $>0$ which were utilized to estimate model coefficients for $T$.

same systems as those used in the component analysis, were used to compare the extraction approaches. Again, as the lack of TAG content could reflect poor condition, individuals analysed whole with no measurable TAG (i.e. $\left.[T]_{\mathrm{W}}=0\right)$ and individuals with a whole body TAG concentration estimate derived from component analysis that was zero (i.e. $[T]_{\mathrm{E}}=0$ ) were excluded when fitting allometric models. Both extraction methods revealed a similar pattern of TAG accumulation (Fig. 5), with low concentrations and no significant increase with $L_{S}$ in size classes I and II followed by a rapid increase in larger individuals (Table II). In the largest individuals, however,

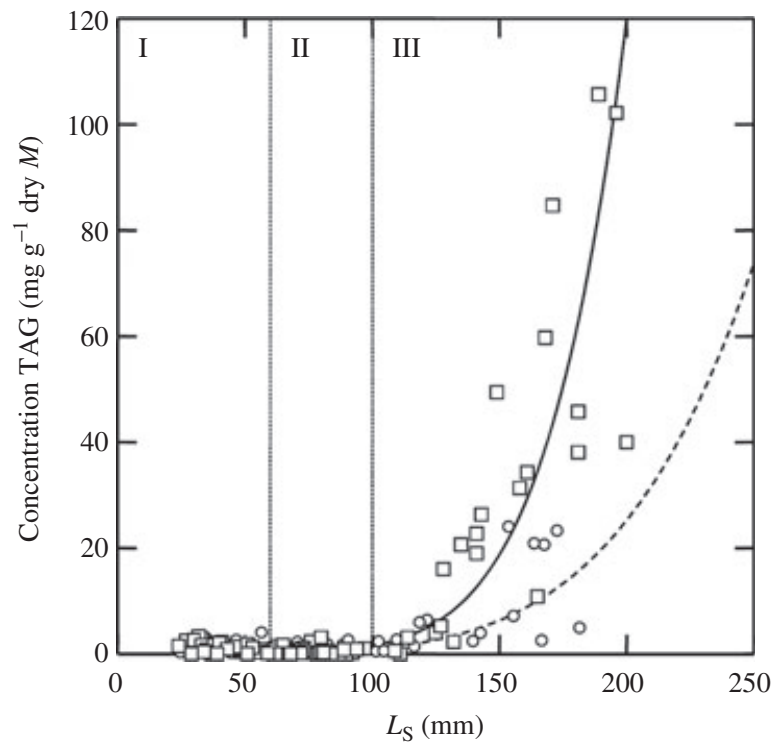

FIG. 5. Concentration of triacylglycerol (TAG) estimated from separate extractions of carcasses, liver and viscera (O) and from extraction of amalgamated whole fish samples $(\square)$ as a function of standard length $\left(L_{S}\right)$ in juvenile Cynoscion regalis from stages I to III. Stage III allometric model fits (see Table II for coefficient estimates) for estimation from separate tissues (_. _. ) and extraction of whole fish samples $(-)$. 
while TAG concentrations from both methods increased with length at similar rates (GLM, $P>0.05$ ), the estimate of TAG concentration at length calculated from whole body extractions was higher than from component analysis (ANCOVA, $P<0.005$ ).

\section{DISCUSSION}

By analysing YOY C. regalis sampled over several seasons, from a range of habitats and throughout their period of estuarine residency, it was possible to determine the general patterns of lipid class dynamics and the location and patterns of energy storage during their period of juvenile estuarine residency. As shown for other species (Norton et al., 2001; Eldridge et al., 2002; Hurst \& Conover, 2003; Berkeley et al., 2004), an understanding of lipid class dynamics and changes in energy stores is needed for comparing condition among individuals across a range of sizes or ontogenetic life stages. For juvenile $C$. regalis, differences in energy storage associated with size class were expected because changes in diet and energetic demands are related to growth and seasonal period, i.e. larger individuals collected later in the YOY period would be expected to invest in long-term energy reserves in order to avoid mortality due to overwinter starvation (Nemerson, 2001; Hurst \& Conover, 2003; Hurst, 2007). While the changes in lipid class distribution and energy dynamics associated with ontogenetic changes are expected to be continuous, the use of a size class-specific model for TAG provided an accurate representation of lipid class and energy storage dynamics across the three ontogenetic classes represented in this study, suggesting that there may be rapid shifts in lipid metabolism associated with growth during the first year of life.

The increase in total lipid concentrations in YOY C. regalis indicates greater allocation of energy to reserves with size, a pattern seen in a wide variety of species (Shulman \& Love, 1999). While total lipid concentration or content is often used as an indicator of condition, the analysis of individual lipid classes has been demonstrated to be a more sensitive indicator of biochemical condition in juvenile and anadromous fishes (Jobling et al., 1998; Norton et al., 2001; Lochmann \& Ludwig, 2003). Among the classes, TAG most often varies with feeding success and environmental factors and is often cited as a direct measure of individual condition (Håkanson, 1989; Weber et al., 2003; Heintz et al., 2004; Naesje et al., 2006; Amara et al., 2007; Weinstein et al., 2009, 2010). While low or absent in the majority of fish $<100 \mathrm{~mm} L_{\mathrm{S}}$, TAG accounted for up to $c .75 \%$ of the total lipids in larger individuals, comparable with the highest reported values for juvenile fishes. Concentrations of FFA also rose with $L_{S}$, however, FFA are produced by enzymatic hydrolysis of phospholipids or TAG and therefore may have evolved from the utilization of endogenous sources or have accumulated post-mortem or while frozen (Parrish, 1987; Heintz et al., 2004). Also, FFA concentrations were low relative to TAG over the range of sizes where TAG accounted for a significant proportion of total lipid content. For these two reasons, concentrations of FFA do not present a strong candidate as the primary form of lipid stores in juvenile $C$. regalis. The unlikely role of FFA, consistently low concentrations of wax esters (another possible form of storage lipids) and the correlation between the rapid increase in TAG and total lipid concentrations indicate that TAG is the primary form of storage lipids in YOY C. regalis. 
Both sterols and phospholipids have been utilized as an indicator of mass change and to standardize lipid energy reserves for comparisons among individual larval fishes (Fraser et al., 1988; Håkanson, 1989). Cynoscion regalis, however, are similar to juveniles of other species, in that concentrations of both classes exhibited fluctuations over their size range and may decline in individuals $>100 \mathrm{~mm} L_{S}$, therefore making both unsuitable as indicators of changes in $M$ (Norton et al., 2001; Lochmann \& Ludwig, 2003; Heintz et al., 2004). While a decline in PL may reflect catabolism due to starvation and PL has been used as an indicator of condition in larval fishes (Håkanson, 1993), it is improbable that the decline seen in this study is due to poor condition as TAG increased rapidly over the size class where PL fell (Norton et al., 2001).

While the variability in TAG concentrations due to feeding or environmental conditions was not directly addressed, its dominant role in the accumulation of lipid energy reserves indicates its utility as a measure of biochemical condition in juvenile C. regalis (Norton et al., 2001). Because of its relationship with $L_{S}$ and the inability to use ST or PL to standardize for differences in $M$ among individuals, caution must be taken to normalize TAG concentration with $L_{\mathrm{S}}$ when comparing condition among individuals > $100 \mathrm{~mm} L_{\mathrm{S}}$ (Lochmann et al., 1995; Lochmann \& Ludwig, 2003).

Many species utilize the liver as their primary lipid reserve (Shulman \& Love, 1999), e.g. the gobies Gobius niger L. 1758 and Zosterisessor ophiocephalus (Pallas 1814) (Fiorin et al., 2007). Similar to many salmonids (Jobling et al., 1998; Morgan et al., 2002), however, analysis of probable depots of TAG revealed the vast majority (c. 95\%) was stored in the carcass, indicating that YOY C. regalis liver and viscera play a minor role in long-term storage of lipid reserves. While few studies have investigated the distribution of specific lipid classes among tissues in fishes (Sheridan et al., 1983; Phleger et al., 1995; Jobling et al., 1998; Rodriguez et al., 2004), the dominant role of TAG in juvenile $C$. regalis lipid stores validates comparisons with studies where storage among specific tissues was determined via analysis of total lipids.

While analysis of separate components was necessary to address the location of long-term storage depots in juvenile $C$. regalis, results from the analysis of components and from samples derived from amalgamated individuals revealed a similar pattern of rapid TAG accumulation in juveniles $>c$. $100 \mathrm{~mm} L_{\mathrm{S}}$. This indicated that the extraction of amalgamated individuals was adequate for assessing juvenile C. regalis condition. Although both methods predicted a similar rate of increase in the concentration of TAG in juveniles $>100 \mathrm{~mm} L_{\mathrm{S}}$, however, whole body analysis provided a significantly higher estimate of TAG concentration at a given $L_{S}$. There are two probable explanations for this discrepancy. First, a $50 \mathrm{mg}$ sub-sample from an amalgamated individual juvenile $C$. regalis may consistently underrepresent tissues with lower concentrations of TAG. More probably, however, the average condition of the largest individuals selected for the component analysis was relatively low. Three of the seven $C$. regalis $>150 \mathrm{~mm} L_{\mathrm{S}}$ selected for component analysis had estimated whole body TAG concentrations lower than the lowest measurement from any amalgamated individual in this same size range. Because liver, viscera and remaining carcass for a given individual were not extracted or analysed together, if these low estimates of whole body TAG concentration resulted from methodological issues, the estimated distribution of TAG stores among the components would be affected. The mean proportion of TAG stored in the carcasses of these three fish was $92 \%$, however, 
near the overall mean of $95 \%$, and well within the variability exhibited across all juveniles used in the component analysis. Furthermore, the mass of components from these individuals ( $>13 \mathrm{~g}$ for carcasses and $>200 \mathrm{mg}$ for livers and viscera) did not require any methodological differences relative to amalgamated individuals, i.e. each component was ground to a find powder and a $50 \mathrm{mg}$ sub-sample selected for extraction and analysis. While analysis of an amalgamated whole juvenile $C$. regalis may be the preferred method to access their condition, caution must be taken not to confuse this approach with the analysis of only muscle tissue. Studies on salmonid species have demonstrated that $>35 \%$ of TAG stores are located in the remaining tissue after the removal of viscera, liver and muscle tissue (only the head, fins, skeletal tissue and skin remain), with upwards of $13.5 \%$ specifically located in the skeletal tissue (Phleger et al., 1989; Jobling et al., 1998). Therefore, samples containing solely muscle tissue may underestimate the TAG stores in juvenile $C$. regalis.

Cynoscion regalis recruits settle throughout the marshes and open waters of Delaware Bay from the late spring into the early autumn with stage I-III juveniles found across the system from July through to October (Paperno et al., 2000). Generally YOY $C$. regalis exhibit 'saltatory' behaviour with growth (Litvin \& Weinstein, 2004), exiting their settlement habitats then moving down estuary varying distances and residing in open waters for extended periods before arriving at the mouth of Delaware Bay prior to emigration (Chao \& Musick, 1977; Weinstein \& Brooks, 1983). Across this mosaic of habitats, juvenile C. regalis may experience a wide range of turbidity and illumination levels, physicochemical conditions, feeding success and predation levels (Lankford \& Targett, 1994; Grecay \& Targett, 1996b), which drive variable growth and mortality rates (Paperno et al., 2000; Nemerson \& Able, 2004). Like other YOY temperate fish species that occur in complex and dynamic ecosystems, juvenile $C$. regalis face competing energetic demands for growth and energy reserves to avoid both size-selective predation and overwintering starvation. The relative importance of these two forces is thought to shift energy allocation from growth to storage over the juvenile period and may be associated with ontogenetic changes in diet and the impending winter season (Sogard, 1997; Post \& Parkinson, 2001; Hurst \& Conover, 2003). The absence of significant TAG reserves in smaller $C$. regalis (stage I and II) indicates that they may have invested primarily in growth to balance the high predation rates they probably encounter early in the juvenile period (Paperno et al., 2000). Later in the juvenile period, two factors may have driven the rapid accumulation of energy reserves stored as TAG, in juvenile C. regalis $>100 \mathrm{~mm} L_{\mathrm{S}}$ (stage III). First, their increase in piscivory (Chao \& Musick, 1977; Nemerson, 2001) represents an important expansion in the ontogenetic niche of juvenile $C$. regalis and probably increases the magnitude of energy they can acquire for storage or growth (Werner \& Gilliam, 1984; Sogard, 1997; Post, 2003). Second, larger fish from later in the YOY period who are preparing to emigrate (Chao \& Musick, 1977; Weinstein \& Brooks, 1983) would be expected to allocate a greater proportion of energy to stores in order to avoid mortality due to starvation while overwintering (Hurst, 2007), a pattern exhibited by several species of temperate YOY fishes (Hurst \& Conover, 2003; Borcherding et al., 2007; Berg et al., 2009).

In conclusion, the present study has demonstrated that the analysis of lipid class dynamics, in the context of growth of juvenile $C$. regalis collected over their YOY period and across a range of estuarine habitats, can provide a useful indicator of individual condition. While measures of total lipid content may be easily acquired, 
as has been demonstrated for other fish species, the quantification of individual lipid class, particularly TAG, allows for a more accurate metric of condition. The elevated TAG concentrations in stage III juveniles indicate that this approach is best suited for assessing condition in larger individuals and is not applicable to fish $<60 \mathrm{~mm} L_{\mathrm{S}}$. The results also indicate that ST or PL cannot be used to account for changes in $M$ or to standardize TAG reserves. Therefore, the use of TAG as a metric of condition must be normalized with $L_{\mathrm{S}}$ when comparing among individuals. Finally, liver and viscera (including mesenteries) do not represent a significant depot for TAG stores in juvenile $C$. regalis, hence extraction of samples derived from amalgamated whole fish provides an accurate estimate of condition while minimizing effort and errors associated with analysis of separate tissues or organs.

Funding was provided by grants NA 86FD0109 [National Oceanic and Atmospheric Administration (NOAA) Saltonstall-Kennedy (SK)] and NA 17RG1396 [NOAA Aquatic Nuisance Species (ANS)], the Marsh Ecology Research Program and the Estuary Enhancement Program (EEP). We thank J. Balletto of the EEP for his support and A. Carlisle and two anonymous reviewers for their comments.

\section{References}

Amara, R., Meziane, T., Gilliers, C., Hermell, G. \& Laffargue, P. (2007). Growth and condition indices in juvenile sole Solea solea measured to assess the quality of essential fish habitat. Marine Ecology Progress Series 351, 201-208.

Bagenal, T. B. \& Tesch, F. W. (1978). Age and growth. In Methods for Assessment of Fish Production in Fresh Waters (Bagenal, T. B., ed.), pp. 101-136. Oxford: Blackwell Scientific Publications.

Berg, O. K., Finstad, A. G., Solem, O., Ugedal, O., Forseth, T., Niemela, E., Arnekleiv, J. V., Lohrmann, A. \& Naesje, T. F. (2009). Pre-winter lipid stores in young-of-year Atlantic salmon along a north-south gradient. Journal of Fish Biology 74, 1383-1393.

Berkeley, S. A., Chapman, C. \& Sogard, S. M. (2004). Maternal age as a determinant of larval growth and survival in a marine fish, Sebastes melanops. Ecology 85, 1258-1264.

Biro, P. A., Morton, A. E., Post, J. R. \& Parkinson, E. A. (2004). Over-winter lipid depletion and mortality of age-0 rainbow trout (Oncorhynchus mykiss). Canadian Journal of Fisheries and Aquatic Sciences 61, 1513-1519.

Black, D. \& Love, R. M. (1986). The sequential mobilization and restoration of energy reserves in tissues of Atlantic cod during starvation and refeeding. Journal of Comparative Physiology B 156, 469-479.

Borcherding, J., Hermasch, B. \& Murawski, P. (2007). Field observations and laboratory experiments on growth and lipid content of young-of-the-year perch. Ecology of Freshwater Fish 16, 198-209.

Chao, L. N. \& Musick, J. A. (1977). Life-history, feeding-habits, and functional-morphology of juvenile Sciaenid fishes in York River Estuary, Virginia. Fishery Bulletin 75, $657-702$.

Cleveland, W. S. (1981). Lowess - a program for smoothing scatterplots by robust locally weighted regression. American Statistician 35, 54.

Deegan, L. A., Hughes, J. E. \& Rountree, R. A. (2000). Salt marsh ecosystem support of marine transient species. In Concepts and Controversies in Tidal Marsh Ecology (Weinstein, M. P. \& Kreeger, D. A., eds), pp. 333-365. Dordrecht: Kluwer Academic Publishers.

Doucett, R. R., Booth, R. K., Power, G. \& McKinley, R. S. (1999). Effects of the spawning migration on the nutritional status of anadromous Atlantic salmon (Salmo salar): insights from stable-isotope analysis. Canadian Journal of Fisheries and Aquatic Sciences 56, 2172-2180. 
Eldridge, M. B., Norton, E. C., Jarvis, B. M. \& MacFarlane, R. B. (2002). Energetics of early development in the viviparous yellowtail rockfish. Journal of Fish Biology 61, $1122-1134$.

Finstad, A. G., Ugedal, O., Forseth, T. \& Naesje, T. F. (2004). Energy-related juvenile winter mortality in a northern population of Atlantic salmon (Salmo salar). Canadian Journal of Fisheries and Aquatic Sciences 61, 2358-2368.

Fiorin, R., Malavasi, S., Franco, A. \& Franzoi, P. (2007). Comparative energy allocation in two sympatric, closely related gobies: the black goby Gobius niger and the grass goby Zosterisessor ophiocephalus. Journal of Fish Biology 70, 483-496.

Folch, J., Lees, M. \& Stanley, G. H. S. (1957). A simple method for the isolation and purification of total lipids from animal tissues. Journal of Biological Chemistry 226, 497-509.

Fraser, A. J., Gamble, J. C. \& Sargent, J. R. (1988). Changes in lipid-content, lipid class composition and fatty-acid composition of developing eggs and unfed larvae of cod (Gadus morhua). Marine Biology 99, 307-313.

Grecay, P. A. \& Targett, T. E. (1996a). Effects of turbidity, light level and prey concentration on feeding of juvenile weakfish Cynoscion regalis. Marine Ecology Progress Series 131, $11-16$.

Grecay, P. A. \& Targett, T. E. (1996b). Spatial patterns in condition and feeding of juvenile weakfish in Delaware Bay. Transactions of the American Fisheries Society 125, 803-808.

Håkanson, J. L. (1989). Analysis of lipid components for determining the condition of anchovy larvae, Engraulis mordax. Marine Biology 102, 143-151.

Håkanson, J. L. (1993). Nutritional condition and growth-rate of anchovy larvae (Engraulis mordax) in the California Current - 2 contrasting years. Marine Biology 115, 309-316.

Heintz, R. A., Nelson, B. D., Hudson, J., Larsen, M., Holland, L. \& Wipfli, M. (2004). Marine subsidies in freshwater: effects of salmon carcasses on lipid class and fatty acid composition of juvenile coho salmon. Transactions of the American Fisheries Society 133, $559-567$.

Houde, E. D. (1987). Fish early life dynamics and recruitment variability. American Fisheries Society Symposium 2, 17-29.

Hurst, T. P. (2007). Causes and consequences of winter mortality in fishes. Journal of Fish Biology 71, 315-345.

Hurst, T. P. \& Conover, D. O. (2003). Seasonal and interannual variation in the allometry of energy allocation in juvenile striped bass. Ecology 84, 3360-3369.

Jobling, M., Johansen, S. J. S., Foshaug, H., Burkow, I. C. \& Jorgensen, E. H. (1998). Lipid dynamics in anadromous Arctic charr, Salvelinus alpinus (L.): seasonal variations in lipid storage depots and lipid class composition. Fish Physiology and Biochemistry 18, $225-240$.

Kneib, R. T. (2003). Bioenergetic and landscape considerations for scaling expectations of nekton production from intertidal marshes. Marine Ecology Progress Series 264, 279-296.

Lankford, T. E. \& Targett, T. E. (1994). Suitability of estuarine nursery zones for juvenile weakfish (Cynoscion regalis) - effects of temperature and salinity on feeding, growth and survival. Marine Biology 119, 611-620.

Litvin, S. Y. \& Weinstein, M. P. (2004). Multivariate analysis of stable-isotope ratios to infer movements and utilization of estuarine organic matter by juvenile weakfish (Cynoscion regalis). Canadian Journal of Fisheries and Aquatic Sciences 61, 1851-1861.

Lochmann, S. E. \& Ludwig, G. M. (2003). Relative triacylglycerol and morphometric measures of condition in sunshine bass fry. North American Journal of Aquaculture 65, 191-202.

Lochmann, S. E., Maillet, G. L., Frank, K. T. \& Taggart, C. T. (1995). Lipid class composition as a measure of nutritional condition in individual larval Atlantic cod (Gadus morhua). Canadian Journal of Fisheries and Aquatic Sciences 52, 1294-1306.

Lochmann, S. E., Maillet, G. L., Taggart, C. T. \& Frank, K. T. (1996). Effect of gut contents and lipid degradation on condition measures in larval fish. Marine Ecology Progress Series 134, 27-35. 
Morgan, I. J., McCarthy, I. D. \& Metcalfe, N. B. (2002). The influence of life-history strategy on lipid metabolism in overwintering juvenile Atlantic salmon. Journal of Fish Biology 60, 674-686.

Naesje, T. F., Thorstad, E. B., Forseth, T., Aursand, M., Saksgard, R. \& Finstad, A. G. (2006). Lipid class content as an indicator of critical periods for survival in juvenile Atlantic salmon (Salmo salar). Ecology of Freshwater Fish 15, 572-577.

Nemerson, D. M. (2001). Trophic dynamics and habitat ecology of the dominant fish of Delaware Bay (USA) Marsh Creeks. Doctoral Thesis, Rutgers University, New Brunswick, NJ, USA.

Nemerson, D. M. \& Able, K. W. (2004). Spatial patterns in diet and distribution of juveniles of four fish species in Delaware Bay marsh creeks: factors influencing fish abundance. Marine Ecology Progress Series 276, 249-262.

Norton, E. C., MacFarlane, R. B. \& Mohr, M. S. (2001). Lipid class dynamics during development in early life stages of shortbelly rockfish and their application to condition assessment. Journal of Fish Biology 58, 1010-1024.

Ohman, M. D. (1996). Freezing and storage of copepod samples for the analysis of lipids. Marine Ecology Progress Series 130, 295-298.

Paperno, R., Targett, T. E. \& Grecay, P. A. (2000). Spatial and temporal variation in recent growth, overall growth, and mortality of juvenile weakfish (Cynoscion regalis) in Delaware Bay. Estuaries 23, 10-20.

Parrish, C. C. (1987). Separation of aquatic lipid classes by chromarod thin-layer chromatography with measurement by Iatroscan flame ionization detection. Canadian Journal of Fisheries and Aquatic Sciences 44, 722-731.

Phleger, C. F., Laub, R. J. \& Benson, A. A. (1989). Skeletal lipid depletion in spawning salmon. Lipids 24, 286-289.

Phleger, C. F., Laub, R. J. \& Wambeke, S. R. (1995). Selective skeletal fatty-acid depletion in spawning pacific pink salmon, Oncorhynchus gorbuscha. Comparative Biochemistry and Physiology B 111, 435-439.

Post, D. M. (2003). Individual variation in the timing of ontogenetic niche shifts in largemouth bass. Ecology 84, 1298-1310.

Post, J. R. \& Lee, J. A. (1996). Metabolic ontogeny of teleost fishes. Canadian Journal of Fisheries and Aquatic Sciences 53, 910-923.

Post, J. R. \& Parkinson, E. A. (2001). Energy allocation strategy in young fish: allometry and survival. Ecology 82, 1040-1051.

Post, J. R., Johannes, M. R. S. \& McQueen, D. J. (1997). Evidence of density-dependent cohort splitting in age-0 yellow perch (Perca flavescens): potential behavioral mechanisms and population-level consequences. Canadian Journal of Fisheries and Aquatic Sciences 54, 867-875.

Ralston, S. (1995). The influence of oceanographic variables on time series of otolith growth in pelagic young-of-the-year rockfish, Sebastes spp. Belle W. Baruch Library in Marine Science 19, 97-118.

Rodriguez, C., Acosta, C., Badia, P., Cejas, J. R., Santamaria, F. J. \& Lorenzo, A. (2004). Assessment of lipid and essential fatty acids requirements of black seabream (Spondyliosoma cantharus) by comparison of lipid composition in muscle and liver of wild and captive adult fish. Comparative Biochemistry and Physiology B 139, 619-629.

Schultz, E. T. \& Conover, D. O. (1997). Latitudinal differences in somatic energy storage: adaptive responses to seasonality in an estuarine fish (Atherinidae: Menidia menidia). Oecologia 109, 516-529.

Schultz, E. T. \& Conover, D. O. (1999). The allometry of energy reserve depletion: test of a mechanism for size-dependent winter mortality. Oecologia 119, 474-483.

Sheridan, M. A., Allen, W. V. \& Kerstetter, T. H. (1983). Seasonal-variations in the lipidcomposition of the steelhead trout, Salmo gairdneri (Richardson), associated with the parr-smolt transformation. Journal of Fish Biology 23, 125-134.

Shulman, G. E. \& Love, R. M. (1999). The Biochemical Ecology of Marine Fishes. London: Academic Press.

Shuter, B. J. \& Post, J. R. (1990). Climate, population viability, and the zoogeography of temperate fishes. Transactions of the American Fisheries Society 119, 314-336. 
Sogard, S. M. (1997). Size-selective mortality in the juvenile stage of teleost fishes: a review. Bulletin of Marine Science 60, 1129-1157.

Walters, C. J. \& Juanes, F. (1993). Recruitment limitation as a consequence of naturalselection for use of restricted feeding habitats and predation risk-taking by juvenile fishes. Canadian Journal of Fisheries and Aquatic Sciences 50, 2058-2070.

Weber, L. P., Higgins, P. S., Carlson, R. I. \& Janz, D. M. (2003). Development and validation of methods for measuring multiple biochemical indices of condition in juvenile fishes. Journal of Fish Biology 63, 637-658.

Weinstein, M. P. \& Brooks, H. A. (1983). Comparative ecology of nekton residing in a tidal creek and adjacent seagrass meadow - community composition and structure. Marine Ecology Progress Series 12, 15-27.

Weinstein, M. P., Litvin, S. Y. \& Guida, V. A. (2009). Essential fish habitat and wetland restoration success: a tier III approach to the biochemical condition of the common mummichog Fundulus heteroclitus in common reed Phragmites australis and smooth cordgrass Spartina alterniflora dominated salt marshes. Estuaries and Coasts 32, 1011-1022.

Weinstein, M. P., Litvin, S. Y. \& Guida, V. A. (2010). Stable isotope and biochemical composition of white perch in a Phragmities dominated salt marsh and adjacent waters. Wetlands 30, 1181-1191.

Werner, E. E. \& Gilliam, J. F. (1984). The ontogenetic niche and species interactions in size-structured populations. In Annual Review of Ecology and Systematics, Vol. 15 (Johnston, R. F., ed.), pp. 393-426. Palo Alto, CA: Annual Reviews, Inc. 